\title{
Validation of the Korean Version of the Biological Rhythms Interview of Assessment in Neuropsychiatry
}

\author{
Chul-Hyun $\mathrm{Cho}^{1 \star}$, Seo-Yeon Jung ${ }^{2 \star}$, Flávio Kapczinski ${ }^{3,4}$, Adriane R Rosa ${ }^{5,6}$, and Heon-Jeong Lee ${ }^{1,7,8} \bowtie$ \\ ${ }^{1}$ Department of Psychiatry, Korea University College of Medicine, Seoul, Republic of Korea \\ ${ }^{2}$ Department of Psychology, University of British Columbia, Vancouver, Canada \\ ${ }^{3}$ Department of Psychiatry and Behavioural Neurosciences, McMaster University, Hamilton, Ontario, Canada \\ ${ }^{4}$ Department of Psychology, Neuroscience and Behaviour, McMaster University, Hamilton, Ontario, Canada \\ ${ }^{5}$ Laboratory of Molecular Psychiatry, Department of Pharmacology, Universidade Federal do Rio Grande do Sul, Porto Alegre, Brazil \\ ${ }^{6}$ Postgraduate Program of Psychiatry and Behavioral Science and Postgraduate Program of Pharmacology and Therapeutics, \\ Universidade Federal do Rio Grande do Sul, Porto Alegre, Brazil \\ ${ }^{7}$ Department of Biomedical Science, Korea University College of Medicine, Seoul, Republic of Korea \\ ${ }^{8}$ Chronobiology Institute, Korea University, Seoul, Republic of Korea
}

Objective The Biological Rhythms Interview of Assessment in Neuropsychiatry (BRIAN) is a scale used to clinically evaluate disturbances in biological rhythm. In this study, we aimed to examine the reliability and validity of the Korean version of the BRIAN (K-BRI$\mathrm{AN})$ in a Korean population.

Methods A total of 181 participants, including 141 outpatients with bipolar disorder (BD; type I, 62; type II, 79 ) and 40 controls, were recruited. Construct validity was tested by comparing the mean K-BRIAN scores of the BD patients and control subjects. Concurrent validity was tested by evaluating the association between the K-BRIAN and the Morningness-Eveningness Questionnaire (MEQ).

Results The mean K-BRIAN scores of the control subjects and patients with BD differed significantly $(\mathrm{p}<0.001)$. Particularly, the mean K-BRIAN score was considerably lower among control subjects (mean \pm standard deviation $=35.00 \pm 8.88$ ) than among patients with $\mathrm{BD}$ type I $(41.19 \pm 12.10)$ and type II $(50.18 \pm 13.73)$. The Cronbach's alpha for the K-BRIAN was 0.914 . The K-BRIAN was found to correlate with the MEQ ( $\mathrm{r}=-0.45, \mathrm{p}<0.001)$.

Conclusion The findings affirm that the K-BRIAN has good construct validity and internal consistency. This suggests that the K-BRIAN can be used to assess biological rhythms in the Korean population, especially for patients with mood disorder.

Psychiatry Investig 2018;15(12):1115-1120

Key Words BRIAN, Biological rhythm, Validation, Korean version, Bipolar disorder.

\section{INTRODUCTION}

The Biological Rhythms Interview of Assessment in Neuropsychiatry (BRIAN) was developed to clinically assess disturbances in biological rhythm, particularly in patients with mental disorders. ${ }^{1}$ Patients with mood disorders frequently experience circadian rhythm dysregulation, which includes irregular restactivity cycle patterns, abnormal hormone secretion, social

Received: August 13, 2018 Accepted: October 21, 2018

$\triangle$ Correspondence: Heon-Jeong Lee, MD, PhD

Department of Psychiatry, Korea University Hospital, Korea University College of Medicine, 73 Inchon-ro, Seongbuk-gu, Seoul 02841, Republic of Korea Tel: +82-2-920-6721, Fax: +82-2-929-7679, E-mail: leehjeong@korea.ac.kr

*These authors contributed equally to this work.

(a) This is an Open Access article distributed under the terms of the Creative Commons Attribution Non-Commercial License (http://creativecommons.org/licenses/bync/4.0) which permits unrestricted non-commercial use, distribution, and reproduction in any medium, provided the original work is properly cited. rhythm disruptions, and sleep-wake disturbances. ${ }^{2,3}$ The scale aims to measure rhythm impairment in 5 different domains directly related to an individual's daily functioning. ${ }^{1}$ These domains include sleep, activity, social rhythms, and eating pattern. ${ }^{1}$ The scale comprises 18 items, including additional 3 items to determine the predominant rhythm, and all items are scored on a 4-point scale. ${ }^{1}$ The item scores are summed during the final evaluation, and the total scores for the 18 items range from 18 to $72 .{ }^{1}$ A higher score indicates a more severe biological rhythm disturbance. ${ }^{1}$ Currently, the scale is applied as an interviewer-administered questionnaire and has been validated in three different languages that include Portuguese, Spanish, Italian, and English., ${ }^{1,-6}$

Many studies have hypothesized that identifying the link between biological rhythm disturbances and mood disorders may help to explain the etiology of mood disorders, including 
bipolar disorder (BD) and depressive disorders., ${ }^{3,-9}$ Reports have described associations between circadian rhythm abnormalities and mood disorders, given that circadian rhythm desynchronization plays a substantial role in the emergence of sleep disturbances that are closely associated with mood symptoms. ${ }^{10-12}$ Sleep-wake cycle irregularities are commonly observed in patients with mood disorders. ${ }^{13}$ Additionally, shifts in molecular circadian rhythm phases have been reported in patients with $\mathrm{BD}$ in whom phase delays and advances have been associated with different mood episodes, including depressive, manic, and mixed. ${ }^{2,3}$ Accordingly, some chronotherapeutic interventions developed to adjust circadian misalignments, such as bright light therapy (BLT), management of a regular sleep-wake cycle, and interpersonal and social rhythm therapy (IPSRT), have been used successfully to reduce the severity of BD. ${ }^{3,14-16}$ Moreover, the therapeutic mechanisms of lithium and valproate, which are frequently prescribed for the treatment of $\mathrm{BD}$, have been attributed to the influences of these drugs on circadian genes and molecular clocks via the inhibition of glycogen synthase kinase- $3 \beta .^{17,18}$

Therefore, a biological rhythm assessment is not only important for identifying the cause of clinical symptoms, but also for the psychiatric treatment and clinical research of mood disorders. Currently, scales such as Seasonal Pattern Assessment Questionnaire (SPAQ) ${ }^{19}$ and Morningness-Eveningness Questionnaire (MEQ) ${ }^{20}$ are available for evaluating biological rhythm. However, these scales specifically evaluate chronotype or seasonality and are not sufficient for the direct evaluation of a subject's biological rhythm. Given the increasing emphasis on the importance of biological rhythm in the psychiatric field, the BRIAN was developed with a focus on biological rhythm and is considered highly valuable in research and clinical studies.

The objectives of this study were to examine the reliability and validity of the Korean version of the BRIAN (K-BRIAN) by examining the relevance of the scale for identifying circadian rhythm abnormalities. This study acknowledges the clinical relationship of circadian rhythm disturbances with the clinical manifestations of $\mathrm{BD}$. The study was performed under the assumption that the preferred circadian phase may predict sleep and circadian rhythm alterations in patients with $\mathrm{BD}$, given that previous studies have reported a greater circadian preference towards eveningness in many patients with $\mathrm{BD}$ types I and II. ${ }^{8-10,13,21-23}$ Accordingly, we adopted another measure, the MEQ ${ }^{20}$ to test the concurrent validity of the K-BRIAN.

\section{METHODS}

\section{Participants}

One hundred and forty-one patients with a clinical diag- nosis of BD under a subsyndromic clinical condition according to the Diagnostic and Statistical Manual of Mental Disorders, Fifth Edition (DSM-5) ${ }^{24}$ were recruited at 9 different hospitals participating in the Mood Disorder Cohort Research Consortium (MDCRC) study, ${ }^{25}$ including Korea University Anam Hospital, Seoul National University Hospital, Seoul National University Bundang Hospital, Samsung Medical Center, Severance Hospital, Pusan National University Hospital, Gyeongsang National University Hospital, Cheonnam National University Hospital, and the National Center for Mental Health. Cases were diagnosed using the Mini-International Neuropsychiatric Interview (M.I.N.I.). ${ }^{26}$ Sixty-nine subjects were diagnosed with $\mathrm{BD}$ I; the remaining subjects were diagnosed with BD II.

Forty control subjects were drawn randomly from the general population at Korea University Anam Hospital. The control group was balanced in terms of age and sex. In this group, 1 male subject was later excluded from the reliability analysis because he failed to answer all questions from the K-BRIAN during the retest assessment.

Informed consent was obtained from all subjects prior to the study. The research was approved by the Institutional Review Board of the Korea University Anam Hospital (IRB No. 2015AN0239) and conducted in accordance with the Declaration of Helsinki.

\section{Assessments}

The BRIAN comprises 18 items divided into 4 main areas related to circadian rhythm disturbances: sleep, social rhythms, activity, and eating pattern. Three additional items addressed predominant rhythm (i.e., chronotype). Particularly, the BRIAN assesses the frequency of problems related to the maintenance of a regular circadian rhythm. The total BRIAN scores from the 18 items range from 18 to 72 , with higher scores indicating a more severe circadian rhythm disturbance. The BRIAN has been used in previous studies conducted in Brazil, ${ }^{1}$ Spain, ${ }^{27,28}$ and Canada. ${ }^{29}$

The BRIAN was translated from English to Korean by a lead researcher of the MDCRC. Forward-backward translations were used to maintain linguistic and conceptual equivalence. The K-BRIAN can be found in Supplementary Material (in the online-only Data Supplement). Prior to our work with the K-BRIAN, we received approval from the original author, Dr. Kapczinski, ${ }^{1}$ and continued to discuss our progress with this author throughout the study.

The K-BRIAN was applied to the 141 patients with $\mathrm{BD}$ and 40 control subjects recruited for our study. Patients with BD were simultaneously evaluated using the MEQ scale ${ }^{20}$ and KBRIAN. These scales were to compare the abilities of these tests to determine chronotypes. The MEQ scale was designed to 
evaluate chronotype preferences in individuals. It includes 19 items for which all scores are summed in the evaluation. Subjects with higher scores are more likely to be categorized as the morning type, whereas those with lower scores tend to be categorized as the evening type. As previously mentioned, this study presumed that the eveningness chronotype may be used as preliminary evidence in an evaluation of circadian rhythm alterations, as this characteristic is prominent among individuals with $\mathrm{BD}$ or other mood disorders. ${ }^{8-10,13,21,30}$ Additionally, the reliability of K-BRIAN was determined in a testretest evaluation involving 40 control subjects. These subjects were evaluated twice at 4-week intervals, and the time points were identified as pre- and post-K-BRIAN. One male control subject failed to complete the post-K-BRIAN.

\section{Statistical analyses}

SPSS 18.0 for Windows (SPSS Inc., Chicago, IL, USA) was used to perform the statistical analysis. First, a 1-way analysis of variance (ANOVA) was used to test the construct validity of the K-BRIAN. The mean K-BRIAN scores of the patients with $\mathrm{BD}$ and control subjects were compared to examine whether the scale could determine abnormalities in biological rhythms among the former group. Second, the associations between the K-BRIAN and MEQ were analyzed by comparing the mean K-BRIAN and MEQ scores of the patients with BD. The concurrent validity of these scales was evaluated using a Pearson's correlation analysis. Third, Cronbach's alpha was used to evaluate the internal consistency of the K-BRIAN. The test-retest reliability of the pre- and postK-BRIAN scores of the control group were compared using the paired samples t-test.

\section{RESULTS}

\section{Subject characteristics}

The subjects' demographics were analyzed using descriptive statistics (Table 1$)$. The mean ( \pm standard deviation) ages of patients with BD types I and II were $23.32 \pm 2.66$ and $22.87 \pm 2.70$ years, respectively. There were slightly more female than male subjects among all patients with BD types I and II. The mean K-BRIAN score was higher among patients with BD type II $(50.18 \pm 13.73)$ than among patients with BD type I (41.19 \pm 12.10$)$. However, patients with BD type II received lower MEQ scores, compared to those with BD type I. As predicted, the eveningness chronotype was predominant in both groups.

The control group had a mean age of $24.76 \pm 4.46$ years, similar to that of $\mathrm{BD}$ patients. In this group, the male/female ratio was exactly $50 / 50$ because the control subjects were balanced in terms of sex. The mean K-BRIAN and MEQ scores among controls were $36.43 \pm 9.54$ and $35.00 \pm 8.88$, respectively. As in the BD groups, the eveningness chronotype was predominant in the control group.

\section{Comparison of K-BRIAN scores between patients with $\mathrm{BD}$ and control subjects}

As shown in Table 2, the ANOVA revealed significant differences in BRIAN scores $(\mathrm{F}=22.43, \mathrm{p}<0.001)$ among the 3 different groups (BD types I and II and controls). Post hoc comparisons (Tukey HSD test) also indicated a significantly lower mean K-BRIAN score for control subjects than for patients with BD type I $(\mathrm{p}<0.036)$ and BD type II $(\mathrm{p}<0.001)$. Furthermore, the mean K-BRIAN score among patients with BD type II was significantly higher than those among patients with BD type I $(p<0.001)$ and control subjects $(p<0.001)$. This pattern remained when the 5 different domains of the BRIAN were analyzed separately (Table 3 ). The mean scores for each domain of the BRIAN revealed an increasing pattern dependent on the severity of the biological rhythm disruption. Specifically, higher BRIAN scores indicated greater overall biological rhythm disturbances, especially among patients with $\mathrm{BD}$.

Table 1. Characteristics of the study subjects

\begin{tabular}{lccc}
\hline & $\begin{array}{c}\text { BD I } \\
(\mathrm{N}=62)\end{array}$ & $\begin{array}{c}\text { BD II } \\
(\mathrm{N}=79)\end{array}$ & $\begin{array}{c}\text { Control subjects } \\
(\mathrm{N}=40)\end{array}$ \\
\hline Age (year) & $23.32 \pm 2.66$ & $22.87 \pm 2.70$ & $24.76 \pm 4.46$ \\
Sex (M/F) & $43.5 / 56.5(\%)$ & $44.3 / 55.7(\%)$ & $50 / 50(\%)$ \\
Mean K-BRIAN & $41.19 \pm 12.10$ & $50.18 \pm 13.73$ & $36.43 \pm 9.54$ \\
$\quad$ score & & & \\
Mean MEQ score & $33.74 \pm 8.22$ & $28.46 \pm 7.82$ & $35.00 \pm 8.88$ \\
Chronotype & & & \\
$\quad$ Eveningness & 51 & 76 & 36 \\
Intermediate & 11 & 3 & 4 \\
Morningness & 0 & 0 & 0 \\
\hline
\end{tabular}

Values are presented as means \pm standard deviations. BD: bipolar disorder, M: male, F: female, K-BRIAN: Korean version of the biological rhythms interview of assessment in neuropsychiatry, MEQ: morningness-eveningness questionnaire

Table 2. One-way analysis of variance of mean K-BRIAN scores between BD patients and control subjects

\begin{tabular}{lrrrcc}
\hline \multicolumn{1}{c}{ Source } & \multicolumn{1}{c}{ df } & \multicolumn{1}{c}{ SS } & MS & F & p \\
\hline Between groups & 2 & 6731.11 & 3365.56 & 22.43 & $<0.001$ \\
Within groups & 178 & 26713.20 & 150.07 & - & - \\
Total & 180 & 33444.31 & - & - & - \\
\hline
\end{tabular}

K-BRIAN: Korean version of the biological rhythms interview of assessment in neuropsychiatry, BD: bipolar disorder, df: degrees of freedom, SS: sum of squares, MS: mean square, $F$ : $f$ statistic, $p: p$ value 
Table 3. Mean scores on the five domains of the K-BRIAN

\begin{tabular}{lcrr}
\hline \multicolumn{1}{c}{ Domains } & Control subjects & \multicolumn{1}{c}{ BD I } & \multicolumn{1}{c}{ BD II } \\
\hline Sleep & $9.28 \pm 2.64$ & $10.45 \pm 4.19$ & $12.89 \pm 4.27$ \\
Activity & $7.17 \pm 2.36$ & $9.48 \pm 4.17$ & $11.43 \pm 4.47$ \\
Social rhythms & $5.65 \pm 1.92$ & $7.10 \pm 2.62$ & $8.56 \pm 3.32$ \\
Eating pattern & $7.05 \pm 2.59$ & $7.82 \pm 2.92$ & $10.10 \pm 3.55$ \\
Predominant & $5.88 \pm 1.45$ & $6.34 \pm 1.44$ & $7.20 \pm 1.72$ \\
rhythm & & & \\
\hline
\end{tabular}

Values are presented in mean \pm standard deviations. K-BRIAN: Korean version of the biological rhythms interview of assessment in neuropsychiatry, BD: bipolar disorder

\section{Analysis of the correlation between K-BRAIN and MEQ}

The analysis revealed a negative correlation between the 2 scales. A linear correlation was observed between these variables such that the MEQ score decreased as the BRIAN score increased. This pattern was expected because a low MEQ score indicates an eveningness chronotype, while a high BRIAN score reveals biological rhythm disturbances. The correlation had an approximately moderate magnitude or strength and was statistically significant $(\mathrm{r}=-0.45, \mathrm{p}<0.001)$.

\section{Reliability statistics of K-BRIAN}

The K-BRIAN was found to be highly reliable for the evaluation of patients with BD. The Cronbach's alpha value of 0.914 indicated a high level of internal consistency for this scale (Table 4). A test-retest reliability analysis of 39 control subjects revealed a moderate correlation $(\mathrm{r}=0.46, \mathrm{p}<0.001)$ between the pre- $(34.62 \pm 8.66)$ and post-K-BRIAN scores (33.59 \pm 6.92$)$. A paired samples t-test revealed no significant intragroup difference between these pre- and post-K-BRAIN scores $(\mathrm{t}=0.775, \mathrm{p}=0.443)$.

\section{DISCUSSION}

We studied the validity and reliability of the K-BRIAN, which has been used to measure biological rhythm in psychiatric settings. Particularly, subjects with $\mathrm{BD}$, which is known to associate closely with circadian rhythm disturbances, were compared with control subjects, and a significant intergroup difference was confirmed. The reliability of the K-BRIAN, confirmed through this study, was similar to that determined in previous studies of BRIAN. ${ }^{1,4}$ The Cronbach's alpha values for the entire scale and for each item were very good and additionally confirmed the excellent reliability of K-BRIAN.

Biological rhythm can be measured at several stages. The traditional method involves continuous measurement of the core body temperature; ${ }^{31}$ however, most approaches evaluate molecular and behavioral circadian rhythms, wherein the for-
Table 4. Reliability analysis of the K-BRIAN

\begin{tabular}{|c|c|c|c|}
\hline $\begin{array}{c}\text { Item } \\
\text { number }\end{array}$ & $\begin{array}{l}\text { Scale mean if } \\
\text { item deleted }\end{array}$ & $\begin{array}{c}\text { Corrected item to } \\
\text { total correlation }\end{array}$ & $\begin{array}{l}\text { Cronbach's alpha } \\
\text { if item deleted }\end{array}$ \\
\hline 1 & 41.53 & 0.609 & 0.909 \\
\hline 2 & 41.47 & 0.602 & 0.909 \\
\hline 3 & 41.37 & 0.584 & 0.909 \\
\hline 4 & 41.58 & 0.613 & 0.909 \\
\hline 5 & 41.53 & 0.659 & 0.908 \\
\hline 6 & 41.65 & 0.603 & 0.909 \\
\hline 7 & 41.82 & 0.669 & 0.907 \\
\hline 8 & 41.65 & 0.761 & 0.905 \\
\hline 9 & 41.62 & 0.754 & 0.905 \\
\hline 10 & 42.16 & 0.534 & 0.911 \\
\hline 11 & 41.71 & 0.653 & 0.908 \\
\hline 12 & 42.17 & 0.443 & 0.912 \\
\hline 13 & 41.81 & 0.601 & 0.909 \\
\hline 14 & 41.89 & 0.629 & 0.909 \\
\hline 15 & 41.42 & 0.701 & 0.906 \\
\hline 16 & 41.48 & 0.497 & 0.911 \\
\hline 17 & 41.44 & 0.630 & 0.908 \\
\hline 18 & 41.99 & 0.403 & 0.913 \\
\hline 19 & 41.31 & 0.436 & 0.913 \\
\hline 20 & 41.67 & 0.301 & 0.926 \\
\hline 21 & 41.65 & 0.466 & 0.912 \\
\hline Total & & & 0.914 \\
\hline
\end{tabular}

K-BRIAN: Korean version of the biological rhythms interview of assessment in neuropsychiatry

mer can be confirmed by measuring changes in gene expression or hormone secretion and the latter can be measured using actigraphy or wearable devices. ${ }^{12,32-35}$ Molecular-level measurements may be most accurate; however, this method remains cumbersome and invasive and is difficult to apply to a large number of subjects. Furthermore, although actigraphy or wearable devices can provide valuable behavior patternbased information related to biological rhythms, it is difficult to obtain this information directly without wearing a device. A biological rhythm measurement based on the K-BRIAN scale is subject to recall bias and dependent on the reliability of answers, ${ }^{36,37}$ but can be easily evaluated at any time; furthermore, the ability to assess 5 subdomains makes this scale an attractive clinical and research tool. Particularly, given the changes in seasonal characteristics throughout the year and the increased disturbance of circadian rhythms due to increased nighttime light exposure, a consequence of a significantly modernized and developed lifestyle, ${ }^{38,39}$ the K-BRIAN can be useful for measuring disturbances in biological rhythm in a psychiatric context in Korea. 
In the present study, the K-BRIAN score was significantly higher in patients with $\mathrm{BD}$ than in normal controls. This is consistent with previous studies suggesting that patients with $\mathrm{BD}$ exhibit more disturbed biological rhythms as determined by the BRIAN. ${ }^{8}$ Particularly, the higher K-BRIAN score of patients with $\mathrm{BD}$ type II relative to those with type I suggests a stronger association of the former type with biological rhythm disturbances. ${ }^{30}$ This result can be interpreted in the context of previous studies, which reported a close relationship between biological rhythm disturbances and more frequent and severe depressive features in patients with BD II. ${ }^{27,28}$ Further investigation into the relationship between the frequency and severity of mood symptoms and the K-BRIAN will be needed in future. This finding provides important evidence regarding an approach based on biological rhythms in mood disorders research and clinical practices.

The correlation between the MEQ and K-BRIAN was significant and negative and suggested a reasonable degree of concurrent validity. In other words, the lower the MEQ score, the higher the K-BRIAN score. This finding suggests a possible relationship between a biological rhythm disturbance and the eveningness chronotype. Studies have shown that the eveningness chronotype is closely related to $\mathrm{BD}$ or seasonal affective disorder (SAD) ${ }^{40-42}$ From this study, the eveningness chronotype appears more likely to disturb the biological rhythm, and both characteristics are closely related to BD. Patients with the eveningness chronotype often remain awake at night and are very likely to be exposed to inappropriate and unnecessary light while awake. A previous study reported that the molecular circadian rhythms of patients at a high-risk of mood disorder are much more easily disturbed by nighttime light exposure than those of patients at a low-risk..$^{12}$ The absence of the morningness chronotype and relatively high frequency of the eveningness chronotype on the MEQ in this study indicates changes in the lifestyles of modern Korean residents. This suggests that circadian rhythm vulnerability and rhythm disturbance factors such as nighttime light exposure, which is common among individuals with the eveningness chronotype, may induce and aggravate BD.

This study had some limitations. First, the study sample was relatively small. However, the combined group of patients with BD types I and II included a considerable number of subjects, which was superior to the sample sizes of previous BRIAN-related studies. ${ }^{1,4}$ Second, it was difficult to select a scale for comparison with K-BRIAN. Previous studies of BRIAN used the same sleep scale as Pittsburgh Sleep Quality Assessment (PSQI); ${ }^{1}$ however, we selected the MEQ to address biological rhythm. ${ }^{20}$ Although a tool with a stronger focus on biological rhythm would be a better option, the MEQ is currently the best-available comparison tool.
In this study, we validated the Korean version of the BRIAN, a scale actively used for biological rhythm measurements in a psychiatric context, and confirmed its validity and reliability in a Korean population. Notably, we observed a significantly higher K-BRIAN score in patients with BD than in normal subjects and confirmed a significant correlation of this scale with the MEQ. Despite some limitations of the KBRIAN for evaluating biological rhythms, it appears to be a very useful tool for evaluation because it focuses on biological rhythms, unlike other scales that only indirectly measure biological rhythm by evaluating seasonality or chronotype. In the future, the K-BRIAN will likely be used for biological rhythm measurements in various psychiatric areas and for active research and clinical practice pertaining to mood disorders.

\section{Supplementary Materials}

The online-only Data Supplement is available with this article at https://doi.org/10.30773/pi.2018.10.21.1.

\section{Acknowledgments}

This study was supported by the Korea Health 21 R\&D Project, funded by the Ministry of Health \& Welfare, Republic of Korea (HM14C2606) and by the National Research Foundation of Korea (2016M3C7A1904345 and 2017M3A9F1031220).

\section{REFERENCES}

1. Giglio LM, Magalhaes PV, Andreazza AC, Walz JC, Jakobson L, Rucci P, et al. Development and use of a biological rhythm interview. J Affect Disord 2009;118:161-165.

2. Rumble ME, White KH, Benca RM. Sleep disturbances in mood disorders. Psychiatr Clin North Am 2015;38:743-759.

3. Moon JH, Cho CH, Son GH, Geum D, Chung S, Kim H, et al. Advanced circadian phase in mania and delayed circadian phase in mixed mania and depression returned to normal after treatment of bipolar disorder. EBiomedicine 2016;11:285-295.

4. Moro MF, Carta MG, Pintus M, Pintus E, Melis R, Kapczinski F, et al. Validation of the Italian Version of the Biological Rhythms Interview of Assessment in Neuropsychiatry (BRIAN): some considerations on its screening usefulness. Clin Pract Epidemiol Ment Health 2014;10: 48-52.

5. Giglio LM, Magalhães PV, Kapczinski NS, Walz JC, Kapczinski F. Functional impact of biological rhythm disturbance in bipolar disorder. J Psychiatr Res 2010;44:220-223.

6. Guillemin F, Bombardier C, Beaton D. Cross-cultural adaptation of health-related quality of life measures: literature review and proposed guidelines. J Clin Epidemiol 1993;46:1417-1432.

7. Kasper S, Wehr TA. The role of sleep and wakefulness in the genesis of depression and mania. Encéphale 1992;18:45-50.

8. Ahn YM, Chang J, Joo YH, Kim SC, Lee KY, Kim YS. Chronotype distribution in bipolar I disorder and schizophrenia in a Korean sample. Bipolar Disord 2008;10:271-275.

9. Vadnie CA, McClung CA. Circadian rhythm disturbances in mood disorders: insights into the role of the suprachiasmatic nucleus. Neural Plast 2017;2017:1-28.

10. Robillard R, Naismith SL, Hickie IB. Recent advances in sleep-wake cycle and biological rhythms in bipolar disorder. Curr Psychiatry Rep 2013;15:402.

11. Zee PC, Attarian H, Videnovic A. Circadian rhythm abnormalities. Continuum Lifelong Learn Neurol 2013;19:132-147. 
12. Cho CH, Moon JH, Yoon HK, Kang SG, Geum D, Son GH, et al. Molecular circadian rhythm shift due to bright light exposure before bedtime is related to subthreshold bipolarity. Sci Rep 2016;6:31846.

13. Seleem MA, Merranko JA, Goldstein TR, Goldstein BI, Axelson DA, Brent DA, et al. The longitudinal course of sleep timing and circadian preferences in adults with bipolar disorder. Bipolar Disord 2015;17: 392-402.

14. Frank E, Hlastala S, Ritenour A, Houck P, Tu XM, Monk TH, et al. Inducing lifestyle regularity in recovering bipolar disorder patients: results from the maintenance therapies in bipolar disorder protocol. Biol Psychiatry 1997;41:1165-1173.

15. Leibenluft E, Suppes T. Treating bipolar illness: focus on treatment algorithms and management of the sleep-wake cycle. Am J Psychiatry 1999;156:1976-1981.

16. Pail G, Huf W, Pjrek E, Winkler D, Willeit M, Praschak-Rieder N, et al. Bright-light therapy in the treatment of mood disorders. Neuropsychobiology 2011;64:152-162.

17. Padiath QS, Paranjpe D, Jain S, Sharma VK. Glycogen synthase kinase $3 \beta$ as a likely target for the action of lithium on circadian clocks. Chronobiol Int 2004;21:43-55.

18. Li X, Bijur GN, Jope RS. Glycogen synthase kinase-3 $\beta$, mood stabilizers, and neuroprotection. Bipolar Disord 2002;4:137-144.

19. Rosenthal N, Bradt G, Wehr T. Seasonal Pattern Assessment Questionnaire. Bethesda: National Institute of Mental Health; 1987.

20. Horne JA, Ostberg O. A self-assessment questionnaire to determine morningness-eveningness in human circadian rhythms. Int J Chronobiol 1976;4:97-110.

21. Bradley AJ, Webb-Mitchell R, Hazu A, Slater N, Middleton B, Gallagher $\mathrm{P}$, et al. Sleep and circadian rhythm disturbance in bipolar disorder. Psychol Med 2017;47:1678-1689.

22. Wood J, Birmaher B, Axelson D, Ehmann M, Kalas C, Monk K, et al. Replicable differences in preferred circadian phase between bipolar disorder patients and control individuals. Psychiatry Res 2009;166: 201-209.

23. Bullock B, Corlass-Brown J, Murray G. Eveningness and seasonality are associated with the bipolar disorder vulnerability trait. J Psychopathol Behav Asess 2014;36:443-451.

24. Association AP. Diagnostic and Statistical Manual of Mental Disorders (DSM- $\left.5^{\circledR}\right)$. Washington DC: American Psychiatric Pub; 2013.

25. Cho CH, Ahn YM, Kim SJ, Ha TH, Jeon HJ, Cha B, et al. Design and methods of the Mood Disorder Cohort Research Consortium (MDCRC) Study. Psychiatry Investig 2017;14:100-106.

26. Hergueta T, Baker R, Dunbar GC. The Mini-International Neuropsychiatric Interview (MINI): the development and validation of a structured diagnostic psychiatric interview for DSM-IV and ICD-10. J Clin Psychiatry 1998;59(Suppl 20):22-33.

27. Pinho M, Sehmbi M, Cudney L, Kauer-Sant’anna M, Magalhães P, Reinares $\mathrm{M}$, et al. The association between biological rhythms, depres- sion, and functioning in bipolar disorder: a large multi-center study. Acta Psychiatr Scand 2016;133:102-108.

28. Rosa AR, Comes M, Torrent C, Solè B, Reinares M, Pachiarotti I, et al. Biological rhythm disturbance in remitted bipolar patients. Int J Bipolar Disord 2013;1:6.

29. Allega OR, Leng X, Vaccarino A, Skelly M, Lanzini M, Hidalgo MP, et al. Performance of the biological rhythms interview for assessment in neuropsychiatry: an item response theory and actigraphy analysis. J Affect Disord 2018;225:54-63.

30. Chung JK, Lee KY, Kim SH, Kim EJ, Jeong SH, Jung HY, et al. Circadian rhythm characteristics in mood disorders: comparison among bipolar I disorder, bipolar II disorder and recurrent major depressive disorder. Clin Psychopharmacol Neurosci 2012;10:110-116.

31. Refinetti R, Menaker M. The circadian rhythm of body temperature. Physiol Behav 1992;51:613-637.

32. Son GH, Chung S, Choe HK, Kim HD, Baik SM, Lee H, et al. Adrenal peripheral clock controls the autonomous circadian rhythm of glucocorticoid by causing rhythmic steroid production. Proc Natl Acad Sci USA 2008;105:20970-20975.

33. Inouye SI, Kawamura H. Persistence of circadian rhythmicity in a mammalian hypothalamic "island" containing the suprachiasmatic nucleus. Proc Natl Acad Sci USA 1979;76:5962-5966.

34. Lee HA, Lee HJ, Moon JH, Lee T, Kim MG, In H, et al. Comparison of wearable activity tracker with actigraphy for sleep evaluation and circadian rest-activity rhythm measurement in healthy young adults. Psychiatry Investig 2017;14:179-185.

35. Morgenthaler T, Alessi C, Friedman L, Owens J, Kapur V, Boehlecke B, et al. Practice parameters for the use of actigraphy in the assessment of sleep and sleep disorders: an update for 2007. Sleep 2007;30:519-529.

36. Van de Mortel TF. Faking it: social desirability response bias in self-report research. Aust J Adv Nurs 2008;25:40-48.

37. Wherry Sr RJ, Bartlett C. The control of bias in ratings: a theory of rating. Pers Psychol 1982;35:521-551.

38. Lee HS, Kang CM, Kang BW, Kim HK. Seasonal variations of acidic air pollutants in Seoul, South Korea. Atmos Environ 1999;33:3143-3152.

39. Cho CH, Lee HJ, Yoon HK, Kang SG, Bok KN, Jung KY, et al. Exposure to dim artificial light at night increases REM sleep and awakenings in humans. Chronobiol Int 2016;33:117-123.

40. Johansson C, Willeit M, Smedh C, Ekholm J, Paunio T, Kieseppä T, et al. Circadian clock-related polymorphisms in seasonal affective disorder and their relevance to diurnal preference. Neuropsychopharmacology 2003;28:734-739.

41. Lee HJ, Rex KM, Nievergelt CM, Kelsoe JR, Kripke DF. Delayed sleep phase syndrome is related to seasonal affective disorder. J Affect Disord 2011;133:573-579.

42. Murray G, Allen NB, Trinder J. Seasonality and circadian phase delay: prospective evidence that winter lowering of mood is associated with a shift towards Eveningness. J Affect Disord 2003;76:15-22. 


\section{Supplementary Material}

생물학적 리듬 평가 설문지 한국어판

(The Korean version of the Biological Rhythms Interview of Assessment in Neuropsychiatry, K-BRIAN)

아래의 질문에 지난 15 일간의 당신의 상태에 가장 적절한 설명을 고르시오.

수 면

1. 평소 자는 시간에 잠드는 것에 어려움이 있습니까? 얼마나 자주 있습니까?

$\begin{array}{llll}\text { 1. 전혀 없음 } & \text { 2. 드물게 있음 } & \text { 3. 때때로 있음 } & \text { 4. 흔히 있음 }\end{array}$

2. 평소 기상시간대로 깨는데 문제가 있습니까? 얼마나 자주 있습니까?

$\begin{array}{llll}\text { 1. 전혀 없음 } & \text { 2. 드물게 있음 } & \text { 3. 때때로 있음 } & \text { 4. 흔히 있음 }\end{array}$

3. 잠에서 깬 후에 잠자리에서 일어나 나오는데 어려움이 있습니까? 얼마나 자주 있습니까?

$\begin{array}{llll}\text { 1. 전혀 없음 } & \text { 2. 드물게 있음 } & \text { 3. 때때로 있음 } & \text { 4. 흔히 있음 }\end{array}$

4. 당신의 평소 수면량으로 휴식을 취했다는 느낌(스스로 느끼는 안정감 및 운전, 업무과 같은 일상의 수행에서)을 받기 어렵습 니까? 얼마나 자주 그렇습니까?

$\begin{array}{llll}\text { 1. 전혀 없음 } & \text { 2. 드물게 있음 } & 3 \text {. 때때로 있음 } & \text { 4. 흔히 있음 }\end{array}$

5. 당신은 휴식시간에 신경을 끄는 것에 어려움을 느끼셨나요? 얼마나 자주 그렇습니까?

$\begin{array}{llll}\text { 1. 전혀 없음 } & \text { 2. 드물게 있음 } & 3 \text {. 때때로 있음 } & \text { 4. 흔히 있음 }\end{array}$

\section{활 동}

6. 당신은 업무 시에 일을 처리하는데 어려움을 느끼시나요? 얼마나 자주 그렇습니까?
1. 전혀 없음
$\begin{array}{lll}\text { 2. 드물게 있음 } & \text { 3. 때때로 있음 } & \text { 4. 흔히 있음 }\end{array}$

7. 당신은 집안일을 처리하는데 어려움을 겪으시나요? 얼마나 자주 그렇습니까?

$\begin{array}{llll}\text { 1. 전혀 없음 } & \text { 2. 드물게 있음 } & \text { 3. 때때로 있음 } & \text { 4. 흔히 있음 }\end{array}$

8. 당신은 규칙적인 일상생활(예, 출근 버스, 지하철을 타거나 규칙적 운동)을 지키는데 어려움을 느끼시나요? 얼마나 자주 그렇습니까?

$\begin{array}{llll}\text { 1. 전혀 없음 } & \text { 2. 드물게 있음 } & \text { 3. 때때로 있음 } & \text { 4. 흔히 있음 }\end{array}$

9. 당신은 정해진 시간의 일상 활동을 수행하는데 있어서 어려움을 느끼시나요? 얼마나 자주 그렇습니까? $\begin{array}{llll}\text { 1. 전혀 없음 } & \text { 2. 드물게 있음 } & \text { 3. 때때로 있음 } & \text { 4. 흔히 있음 }\end{array}$

10. 당신은 평소의 성욕이나 성적활동을 유지하는데 어려움을 느끼시나요? 얼마나 자주 그렇습니까?
1. 전혀 없음
$\begin{array}{lll}\text { 2. 드물게 있음 } & 3 \text {. 때때로 있음 } & \text { 4. 흔히 있음 }\end{array}$

\section{사회적 활동}

11. 당신은 중요한 다른 사람과의 대인관계나 소통에 있어서 어려움을 느끼시나요? 얼마나 자주 그렇습니까?

$\begin{array}{llll}\text { 1. 전혀 없음 } & \text { 2. 드물게 있음 } & \text { 3. 때때로 있음 } & \text { 4. 흔히 있음 }\end{array}$

12. 당신은 전자기기(TV, 인터넷 등)의 이용에 있어서 대인관계에 지장을 줄 정도로 과도하게 사용하시나요? 얼마나 자주 그렇습니까?

$\begin{array}{llll}\text { 1. 전혀 없음 } & \text { 2. 드물게 있음 } & \text { 3. 때때로 있음 } & \text { 4. 흔히 있음 }\end{array}$

13. 당신의 일상과 수면패턴을 중요한 이들(가족, 친구, 배우자)과 맞추는데 어려움이 있으신가요? 얼마나 자주 그렇습니까? $\begin{array}{llll}\text { 1. 전혀 없음 } & \text { 2. 드물게 있음 } & \text { 3. 때때로 있음 } & \text { 4. 흔히 있음 }\end{array}$

14. 당신은 중요한 이들(가족, 친구, 배우자)에서 관심을 주는 것이 어려움이 있으신가요? 얼마나 자주 그렇습니까? $\begin{array}{llll}\text { 1. 전혀 없음 } & \text { 2. 드물게 있음 } & \text { 3. 때때로 있음 } & \text { 4. 흔히 있음 }\end{array}$

\section{식사 패턴}

15. 당신은 규칙적인 식사시간을 시키는데 어려움이 있으신가요? 얼마나 자주 그렇습니까?
1. 전혀 없음
$\begin{array}{lll}\text { 2. 드물게 있음 } & 3 \text {. 때때로 있음 } & \text { 4. 흔히 있음 }\end{array}$

16. 식사를 거르시나요? 얼마나 자주 그렇습니까?

$\begin{array}{llll}\text { 1. 전혀 없음 } & \text { 2. 드물게 있음 } & \text { 3. 때때로 있음 } & \text { 4. 흔히 있음 }\end{array}$

17. 당신은 식사량을 일정하게 유지하는 것에 어려움이 있으신가요? 얼마나 자주 그렇습니까?

$\begin{array}{llll}\text { 1. 전혀 없음 } & \text { 2. 드물게 있음 } & \text { 3. 때때로 있음 } & \text { 4. 흔히 있음 }\end{array}$

18. 각성제(커피, 콜라, 초코렛 등)의 과도하지 않게 사용하는 것에 어려움이 있으신가요? 얼마나 자주 그렇습니까? $\begin{array}{llll}\text { 1. 전혀 없음 } & \text { 2. 드물게 있음 } & \text { 3. 때때로 있음 } & \text { 4. 흔히 있음 }\end{array}$

\section{시간형}

다음 질문들은 지난 1년간에 관한 것입니다.

19. 밤시간이 업무나 대인관계에 있어서 더 활발하다.
1. 전혀 아니다
2. 거의 아니다 3. 보통 그렇다
4. 항상 그렇다

20. 아침에 좀더 생산적이 되는 느낌이다.
1. 전혀 아니다
2. 거의 아니다 3. 보통 그렇다
4. 항상 그렇다

21. 낮 밤이 뒤바뀌어 살았나요?

1. 전혀 아니다 2 . 거의 아니다 3 . 보통 그렇다 4. 항상 그렇다 